\title{
Merancang Kawasan Konservasi Perairan Berorientasi Perikanan: Studi Kasus Kawasan Konservasi Perairan Pulau Liang dan Pulau Ngali di Nusa Tenggara Barat
}

\author{
Sukmaraharja Aulia ${ }^{1 *}$, Jessica Pingkan', Hernawati', Tezar Rafandi' ${ }^{1}$, Azhar Muttaqin ${ }^{2}$, \\ Muhidin', Heidi Retnoningtyas ${ }^{3}$ \\ ${ }^{1}$ Wildlife Conservation Society, ${ }^{2}$ Kementerian Kelautan dan Perikanan, Direktorat Jenderal \\ Pengelolaan Ruang Laut, BKKPN Kupang, ${ }^{3}$ Bremen University, Jerman \\ *starigan@wcs.org
}

\begin{abstract}
The shape of marine protected areas (MPAs) aimed for fisheries goals should be small enough to allow for spillover of adult fished species as well as larval and juvenile fished species. Such consideration was applied during the establishment of Liang-Ngali Island MPA in West Nusa Tenggara (WNT), Indonesia, which was mainly developed to support fisheries activities around it. In WNT, biologically diverse coastal and marine ecosystems have been utilized by local residents to support their livelihoods, mainly through fisheries and tourism activities. Aside from being a home for unique habitat such as mangrove forest, seagrass beds, and coral reef, Liang and Ngali Island also shows indication of spawning aggregation sites for reef fishes such as groupers and snappers. In 2016, the government of WNT Province designated both islands as marine protected areas under the category of marine recreational park. Following the Governor Decree, a management and zonation plan of Liang-Ngali MPA was then developed by engaging stakeholders from multiple institutions. In the framework of ecosystem approach to fisheries management, the existence of MPA provides strong instrument to support the sustainability of fish resources as well as maintaining continuous livelihood for surrounding coastal communities.
\end{abstract}

Keywords: MPA, Fisheries, Liang-Ngali, WNT

\section{PENDAHULUAN}

Pulau Liang dan Pulau Ngali berada di Kecamatan Lape, Kabupaten Sumbawa dan termasuk dalam wilayah Teluk Saleh dimana ekosistem terumbu karang, mangrove dan lamun berperan penting dalam penyediaan sumber protein hewani laut. Terumbu karang di wilayah TWP Pulau Liang dan Pulau Ngali mempunyai tipe karang tepi (fringing reef). Terumbu karang rata-rata ditemukan pada kedalaman 4-9 meter. Berdasarkan hasil analisis citra, ekosistem terumbu karang di kawasan TWP Pulau Liang dan Pulau Ngali mencakup area seluas 7003,68 ha. Ekosistem ini tersebar di dua utama yaitu Pulau Liang dan Pulau Ngali (DKP NTB 2018). Di satu sisi, kawasan ini juga merupakan area migrasi penting beberapa spesies megafauna laut seperti penyu, hiu paus dan hiu karang. Kawasan pesisir Pulau Liang dan Ngali merupakan salah satu lokasi penangkapan ikan demersal terutama jenis ikan kerapu dan kakap. 
Sebagian besar target tangkapan ikan kakap dan kerapu oleh nelayan di perairan Teluk Saleh berasal dari 71 spesies dan 30 famili (Setiawan et al. 2017).

Rata-rata hasil tangkapan ikan kerapu (Famili Epinephelidae) di Teluk Saleh mencapai 22 kg.hari ${ }^{-1}$. Sementara ikan kakap mencapai 78 kg.hari ${ }^{-1}$. Hasil tangkapan kerapu menyumbang sekitar $1 \%$, sementara hasil tangkapan ikan kakap menyumbang sekitar 5\% dari keseluruhan komposisi hasil tangkapan nelayan (kg) di Teluk Saleh. Beberapa spesies target nelayan yang berasal dari jenis ikan kakap (famili Lutjanidae) antara lain Etelis coruscans, Lutjanus bohar, $L$. argentimaculatus, L. erythropterus dan spesies target yang berasal dari jenis ikan kerapu (famili Epinephelidae) adalah Plectropomus leopardus, P. areolatus, P. maculatus, Variola louti, V. albimarginata, Cephalopholis miniata dan C. Sex maculata(Yulianto et al. 2016). Berdasarkan IUCN RedList, status spesies Plectropomus leopardus termasuk ke dalam kategori rentan (vulnerable) sementara Plectropomus areolatus termasuk ke dalam kategori hampir terancam (near threatened). Sedangkan untuk jenis ikan kerapu dan kakap lainnya umumnya beresiko rendah (least concern). Konsentrasi ikan memijah didominasi oleh ikan kerapu dikarenakan perdagangan ikan konsumsi hidup banyak mengincar kerapu dan menjadi ancaman terhadap lokasi pemijahan kerapu di seluruh dunia, di sisi lain spesies ikan kerapu memiliki siklus hidup panjang dan pertumbuhan yang lambat, sehingga sangat rentan terhadap tekanan perikanan (Morris, Roberts, and Hawkins 2000).

Terdapat permasalahan spesifik di sebagian pesisir Teluk Saleh dimana terjadinya penangkapan ikan yang merusak (destructive fishing) seperti penggunaan bom dan potas, lokasi penangkapan ikan yang semakin jauh, belum adanya aturan di tingkat desa ataupun kabupaten yang mengelola perikanan kakap dan kerapu secara berkelanjutan, serta kurangnya partisipasi dari kelompok masyarakat, pemerintah, pengusaha dan nelayan untuk mengelola perikanan secara berkelanjutan (Rafandi et al. 2017).

Besarnya potensi dan ancaman terhadap ekosistem terumbu karang di lokasi perairan Pulau Liang-Ngali membutuhkan adanya suatu aksi perlindungan yang terpadu. Program perlindungan melalui pembentukan kawasan konservasi perairan daerah yang sedang dilakukan oleh Kementerian Kelautan dan Perikanan (KKP) di seluruh wilayah perairan Indonesia merupakan bentuk nyata dalam mengatasi permasalahan ini dan diharapkan menjadi solusi terbaik dalam mengembalikan potensi sumberdaya laut yang sudah rusak. Pembentukan KKP dapat menguntungkan manajemen perikanan melalui peningkatan stok, keanekaragaman, kepadatan, biomassa, ukuran tubuh dan potensi reproduksi ikan terumbu karang (Lester et al. 2009). Tulisan ini mencoba memaparkan langkah-langkah pembentukan kawasan konservasi perairan dengan tujuan pengelolaan sumberdaya perikanan secara berkelanjutan menggunakan parameter ekologi, sosial ekonomi perikanan, pemetaan habitat pesisir dan pemanfaatan kawasan yang sudah ada dengan mengambil studi kasus di wilayah perairan Pulau Liang dan Pulau Ngali di Teluk Saleh, Sumbawa.

\section{METODE PENELITIAN}

Kajian ekologi dilakukan pada tanggal 9 juni - 27 Juni 2014 dengan jumlah lokasi sebanyak 9 situs pengamatan. Sedangkan kajian pemijahan untuk habitat pemijahan ikan kakap dan kerapu dilakukan melalui dua tahap yaitu pada saat bulan purnama (tanggal 17-19 Agustus 2016) dan di bulan gelap (tanggal 31 Agustus-2 September 2016 (Colin 2006).

Situs pengamatan dipilih untuk mewakili lokasi yang akan diusulkan menjadi kawasan konservasi di setiap wilayah yang akan diusulkan menjadi kawasan konservasi ditentukan juga lokasi yang berada di luar kawasan konservasi perairan sebagai kontrol. Informasi mengenai lokasi survei terumbu karang ditampilkan pada Gambar 1. 


\section{Waktu dan lokasi survey sosial ekonomi perikanan}

Survei dilakukan di enam desa yaitu Desa Batu Bangka (Kecamatan Moyo Hilir), Labuhan Ijuk (Kecamatan Moyo Hilir), Olat Rawa (Kecamatan Moyo Hilir), Labuhan Kuris (Kecamatan Lape), Labuhan Sangoro (Kecamatan Maronge) dan Kukin (Kecamatan Moyo Utara). Survei dilakukan dari tanggal 2 sampai 12 April 2016 (Gambar 1).

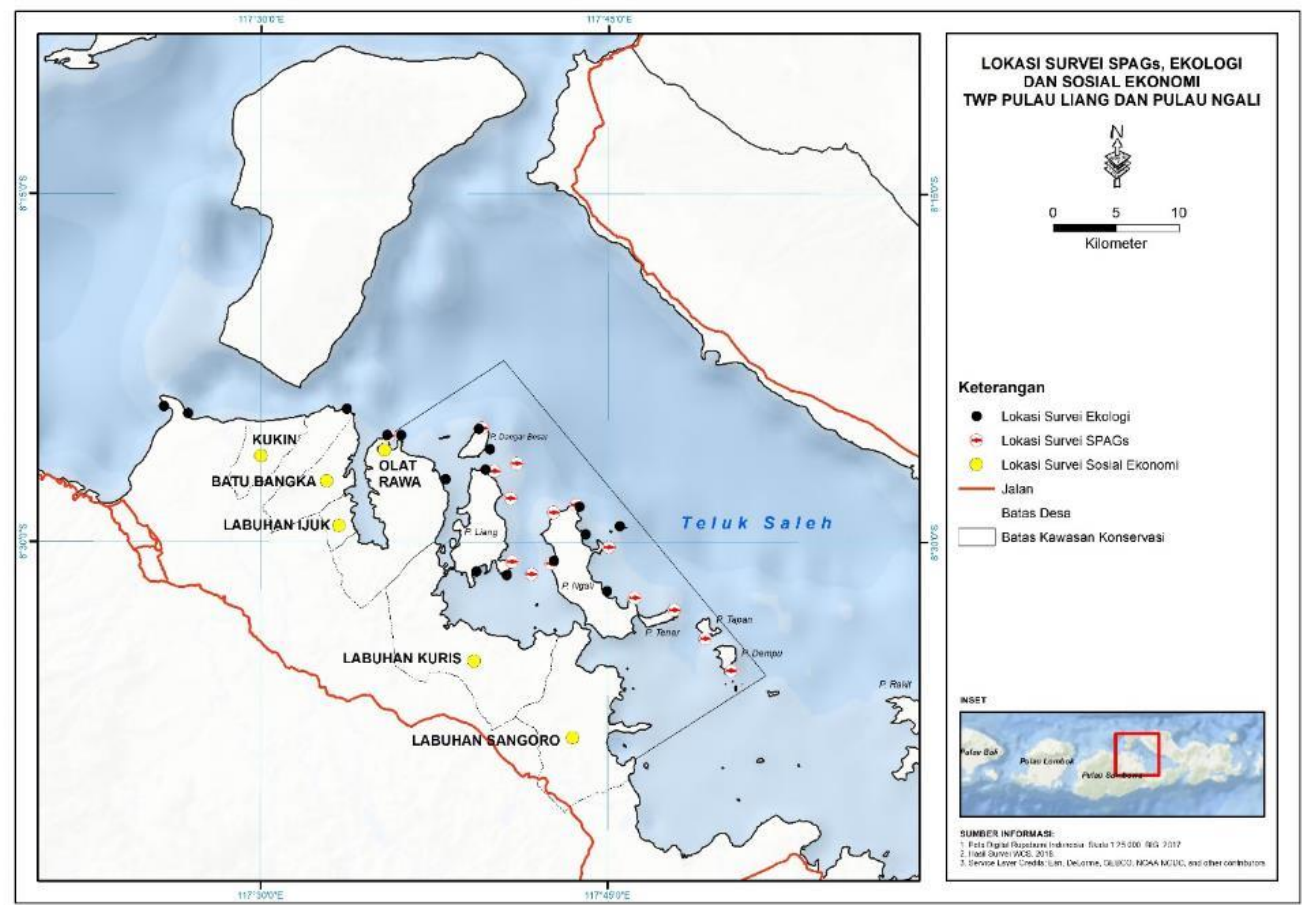

Gambar 1. Lokasi kajian ekologi, pemetaan habitat pemijahan ikan karang dan survei sosial ekonomi di KKP Pulau Liang dan Pulau Ngali

\section{Metode Pengumpulan Data}

Metode pengumpulan data dilakukan secara insitu dengan pengamatan secara langsung untuk keempat parameter data yang dikumpulkan yakni ekologi, sosial ekonomi perikanan, pemetaan pola pemanfaatan Kawasan dan pemetaan ekosistem pesisir. Untuk lebih jelasnya metode pengumpulan data disajikan pada Tabel 1. di bawah ini.

Tabel 1. Metodologi dan analisis setiap parameter yang dikaji

\begin{tabular}{|c|c|c|c|}
\hline Aspek & Parameter & Metode Pengamatan & Analisis Data \\
\hline \multirow{4}{*}{ Ekologi } & Karang keras & $\begin{array}{l}\text { Point Intercept Transect } \\
\text { (Hill and Wilkinson 2004); } \\
\text { (Yulianto et al. 2012) }\end{array}$ & $\frac{\sum \text { titik kategori i }}{\text { Jumlah total titik }} \times 100 \%$ \\
\hline & Karang rekrutment & $\begin{array}{c}\text { Quadrate Transect } \\
\text { (Hill and Wilkinson 2004); } \\
\text { (Yulianto et al. 2012) }\end{array}$ & $\frac{\sum \text { koloni genus ke }-\mathrm{i}}{\mathrm{m}^{2}} \mathrm{X} 4$ \\
\hline & $\begin{array}{l}\text { Kelimpahan ikan } \\
\text { karang }\end{array}$ & \multirow{2}{*}{$\begin{array}{l}\text { Underwater Visual Census } \\
\text { (Hill and Wilkinson 2004); } \\
\text { (Yulianto et al. 2012) }\end{array}$} & $\frac{\sum \text { ikan karang jenis }}{\text { Luas area }}$ \\
\hline & Biomassa ikan karang & & $\mathrm{W}=\mathrm{aL}^{\mathrm{b}}$ \\
\hline
\end{tabular}




\begin{tabular}{|c|c|c|c|}
\hline Aspek & Parameter & Metode Pengamatan & Analisis Data \\
\hline & & & Biomass $=$ Abundance $\times \mathrm{W}(\mathrm{kg} / \mathrm{ha})$ \\
\hline & $\begin{array}{l}\text { Kekayaan spesies } \\
\text { ikan dan genera } \\
\text { terumbu karang }\end{array}$ & $\begin{array}{c}\text { Underwater Visual Census } \\
\text { (Hill and Wilkinson 2004) } \\
\text { dan Time Swim (Hill and } \\
\text { Wilkinson 2004) }\end{array}$ & $\begin{array}{c}3.39 * \text { CFDI }-20.595 \text { untuk } \\
\text { kawasan kurang dari } 2000 \mathrm{~km}^{2}\end{array}$ \\
\hline & Pemijahan ikan & $\begin{array}{l}\text { Underwater Visual Census } \\
\text { (Colin 2006) }\end{array}$ & $\begin{array}{l}\text { Skoring dan pembobotan } \\
\text { menggunakan Corespondence } \\
\text { Analysis(Setiawan et al. 2017) }\end{array}$ \\
\hline & Kepadatan kima & $\begin{array}{l}\text { Belt Intercept Transect } \\
\text { (Hill and Wilkinson 2004); } \\
\text { (Yulianto et al. 2012) }\end{array}$ & $\frac{\sum \text { Kima }}{\text { Luas area }}$ \\
\hline \multirow{2}{*}{$\begin{array}{c}\text { Sosial } \\
\text { ekonomi } \\
\text { perikanan }\end{array}$} & $\begin{array}{l}\text { Jenis dan hasil } \\
\text { tangkapan }\end{array}$ & $\begin{array}{c}\text { Survey Rumah Tangga } \\
\text { (Gurney and Darling 2017) }\end{array}$ & Deskriptif \\
\hline & $\begin{array}{l}\text { Lokasi penangkapan } \\
\text { ikan }\end{array}$ & $\begin{array}{c}\text { Survey Rumah Tangga } \\
\text { (Gurney and Darling 2017) }\end{array}$ & Deskriptif \\
\hline $\begin{array}{c}\text { Pola } \\
\text { pemanfaatan } \\
\text { kawasan }\end{array}$ & $\begin{array}{c}\text { Lokasi pemanfaatan } \\
\text { pariwisata, perikanan, } \\
\text { dan budidaya oleh } \\
\text { masyarakat }\end{array}$ & $\begin{array}{l}\text { Rapid Rural Appraisal } \\
\text { (Freudenberger 1999) }\end{array}$ & Deskriptif \\
\hline \multirow{3}{*}{$\begin{array}{l}\text { Pemetaan } \\
\text { ekosistem } \\
\text { pesisir }\end{array}$} & Ekosistem mangrove & Rapid Rural Appraisal & \multirow{3}{*}{$\begin{array}{l}\text { Analisis Citra dan GIS } \\
\text { menggunakan algoritma Lyzenga } \\
\text { ( McDonnell et al. } 2002 \text { dalam } \\
\text { Ardron, Possingham, \& Klein, } \\
\text { 2010) }\end{array}$} \\
\hline & Ekosistem lamun & (Freudenberger 1999) & \\
\hline & $\begin{array}{l}\text { Ekosistem terumbu } \\
\text { karang }\end{array}$ & & \\
\hline
\end{tabular}

\section{Analisis Skoring dan Pembobotan Habitat Pemijahan Ikan}

Dalam menentukan lokasi perlindungan bagi agregasi pemijahan di KKP Pulau Liang dan Ngali, dilakukan pemberian skor dan bobot untuk masing-masing lokasi berdasarkan beberapa nilai parameter ekologis yaitu jumlah individu per spesies (bobot 2), selang ukuran ikan karang (bobot 3), tanda-tanda pemijahan (bobot 3), dan biota karismatik (bobot 1).

Sementara untuk parameter selang ukuran pembobotan dibagi berdasarkan selang kelas ukuran ikan dimana 0-10 cm diberi skor 1, 10-30 cm diberi skor 2 dan $>30 \mathrm{~cm}$ diberi skor 3 . Untuk analisis tanda-tanda pemijahan dan biota karismatik dilakukan perhitungan dengan cara memberi nilai bobot 1 , jika ditemukan tanda-tanda pemijahan dan nilai bobot 0 , jika tidak ditemukannya tanda-tanda pemijahan. Perlakuan yang sama juga dilakukan untuk biota karismatik.

Nilai skor tersebut kemudian dikalikan dengan nilai bobot yang ditetapkan, sehingga didapatkan nilai total semua parameter ekologis pada setiap lokasi penelitian. Sebaran nilai total perkalian skor dan bobot dari seluruh parameter untuk masing-masing lokasi pengamatan dibagi menjadi 3 kategori dengan menggunakan CI dengan selang kepercayaan 0,05. Sebaran nilai diatas nilai CI masuk dalam kategori baik (warna hijau), sedangkan nilai di bawah CI masuk dalam kategori buruk (warna merah), dan nilai di tengah CI masuk dalam kategori sedang (warna kuning). 
Hasil perhitungan ini kemudian ditampilkan dalam bentuk spasial/peta sesuai pewarnaan untuk tiap kategori.

\section{Analisis Penataan zonasi}

\section{Analisis Marxan}

Marxan adalah perangkat lunak yang dapat membantu pengambilan keputusan, terutama dalam bidang konservasi. Dalam pengaplikasiannya, Marxan mengimplementasikan algoritma yang dikenal dengan simulated annealing untuk menghasilkan solusi yang baik (Ardron at al. 2010). Berikut fungsi objektif dalam Marxan (Game et al. 2008):

$$
\begin{gathered}
\sum_{\text {PUs }} \operatorname{Cost}(1)+B L M \sum_{\text {PUs }} \text { Boundary }(2) \\
+\sum_{\text {ConValue }} \text { SPFXPenalty }(3)+\text { CostThresholdPenalty }(t)(4)
\end{gathered}
$$

Dimana:

1. Nilai yang dihasilkan dari setiap fitur cost dan dibebankan pada setiap unit perencanaan. Nilai ini wajib ada dalam analisis

2. Nilai yang ditentukan dalam proses analisis untuk menentukan konektivitas tiap unit perencanaan. Semakin besar nilai boundary length, semakin mengelompok hasil dari analisis

3. Nilai penalti yang diberikan pada setiap fitur konservasi jika tidak memenuhi nilai konservasi yang telah ditetapkan

4. Denda karena telah melebihi ambang biaya yang ditetapkan

\section{Unit Perencanaan (Planning Unit)}

Unit perencanaan adalah sebuah area kajian yang dibagi menjadi unit-unit berbentuk segi enam yang memiliki nilai konservasi dan cost. Semakin kecil ukuran unit analisis akan memberikan hasil yang semakin detail. Pada studi ini, unit perencanaan yang digunakan adalah KKP Pulau Liang dan Ngali yang memiliki luas $33.461 \mathrm{Ha}$ (luas kawasan saat dilakukan analisis dan sebelum penetapan) yang dibagi menjadi 34.883 unit dengan ukuran unit $1 \mathrm{Ha}$.

\section{Data dan Skenario}

Data yang digunakan dalam studi ini berupa data spasial dari fitur konservasi dan fitur cost. Fitur-fitur konservasi yang digunakan, meliputi data tutupan karang dengan target konservasi 10\%, lokasi pemijahan ikan 30\%, biomassa ikan 30\%, kelimpahan ikan 30\%, dan keberadaan lamun dan mangrove dengan target konservasi $10 \%$. Fitur cost yang digunakan, meliputi data aktivitas pola pemanfaatan kegiatan perikanan seperti lokasi penangkapan dengan bobot 10 dan aktivitas nonperikanan seperti keberadaan industri, tambang dan pelabuhan dengan bobot 5. Data-data tersebut kemudian akan dianalisis menggunakan program Marxan dengan lima skenario berbeda (Tabel 2).

Tabel 2. Skenario analisis Marxan

\begin{tabular}{llllllll}
\hline Skenario & Fitur Konservasi & Target & SPF & $\begin{array}{l}\text { Fitur } \\
\text { Biaya }\end{array}$ & $\begin{array}{l}\text { Biaya } \\
\text { Perencanaan }\end{array}$ & $\begin{array}{l}\text { Unit } \\
\text { Perencana }\end{array}$ & $\begin{array}{l}\text { Panjang } \\
\text { Boundari }\end{array}$ \\
\hline & Ekosistem Lamun & $10 \%$ & 10 & & 10 & $1 \mathrm{Ha}$ & 20
\end{tabular}




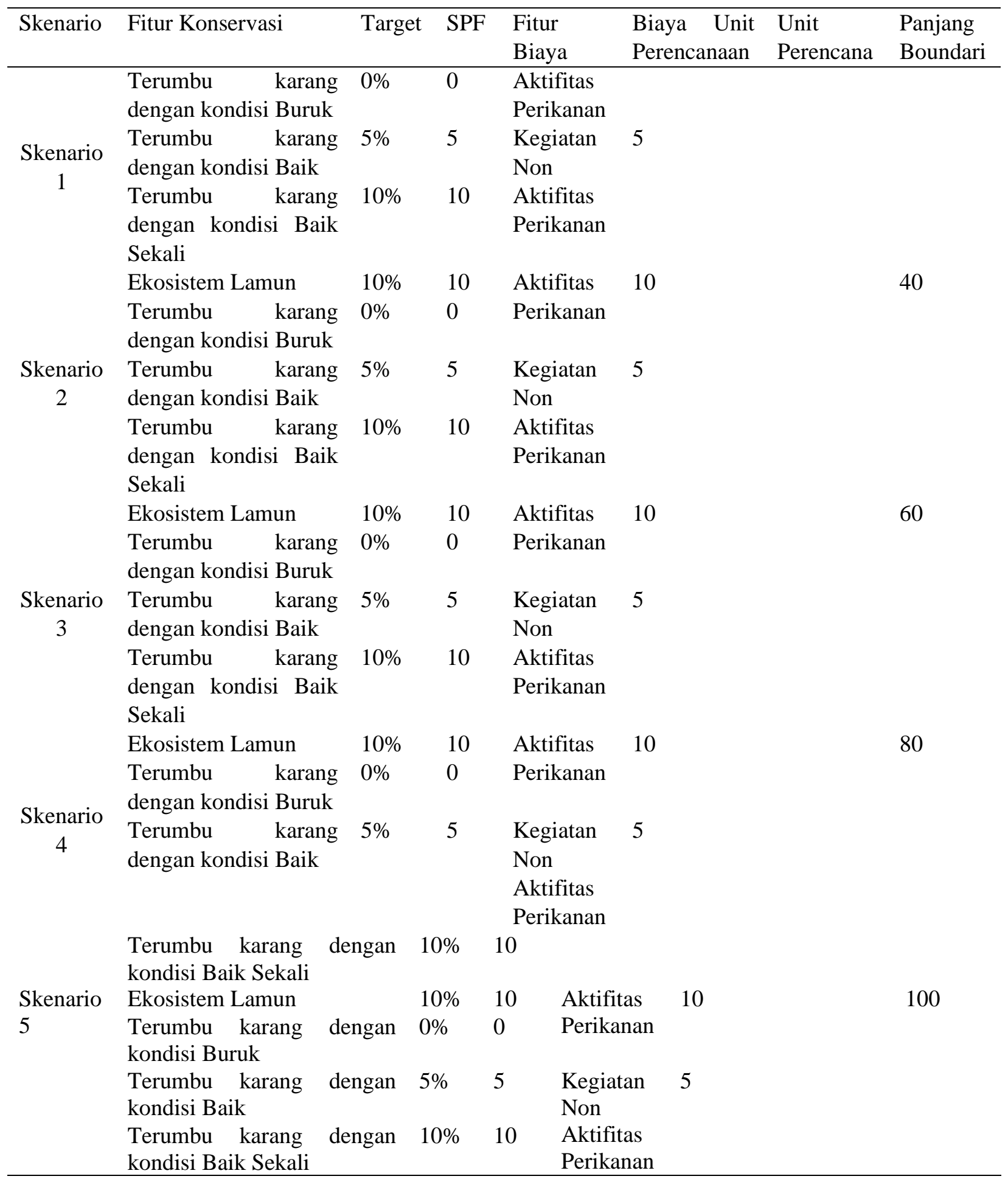

\section{Focus Group Discussion Bersama masyarakat di Sekitar Kawasan konservasi}

Kegiatan konsultasi publik dilaksanakan sebanyak dua kali dengan tujuan memberikan gambaran tentang kondisi potensi ekologis, dan sosial ekonomi budaya masyarakat yang ada di sekitar KKP Pulau Liang dan Pulau Ngali dan mendapatkan masukan dan kesepakaran terkait penyusunan dokumen rencana pengelolaan dan zonasi KKP Pulau Liang dan Pulau Ngali. Konsultasi publik rencana pengelolaan dan 
zonasi KKP Pulau Liang dan Pulau Ngali dilaksanakan pada tanggal 20 Februari 2017 dan 7 Maret 2017. Kegiatan ini dihadiri oleh peserta sebanyak 71 peserta yang berasal dari pemerintah desa, pemerintah kabupaten, akademisi dan pemerintah provinsi Nusa Tenggara Barat. Secara umum diagram alir proses penelitian disajikan pada Gambar 2. di bawah ini.

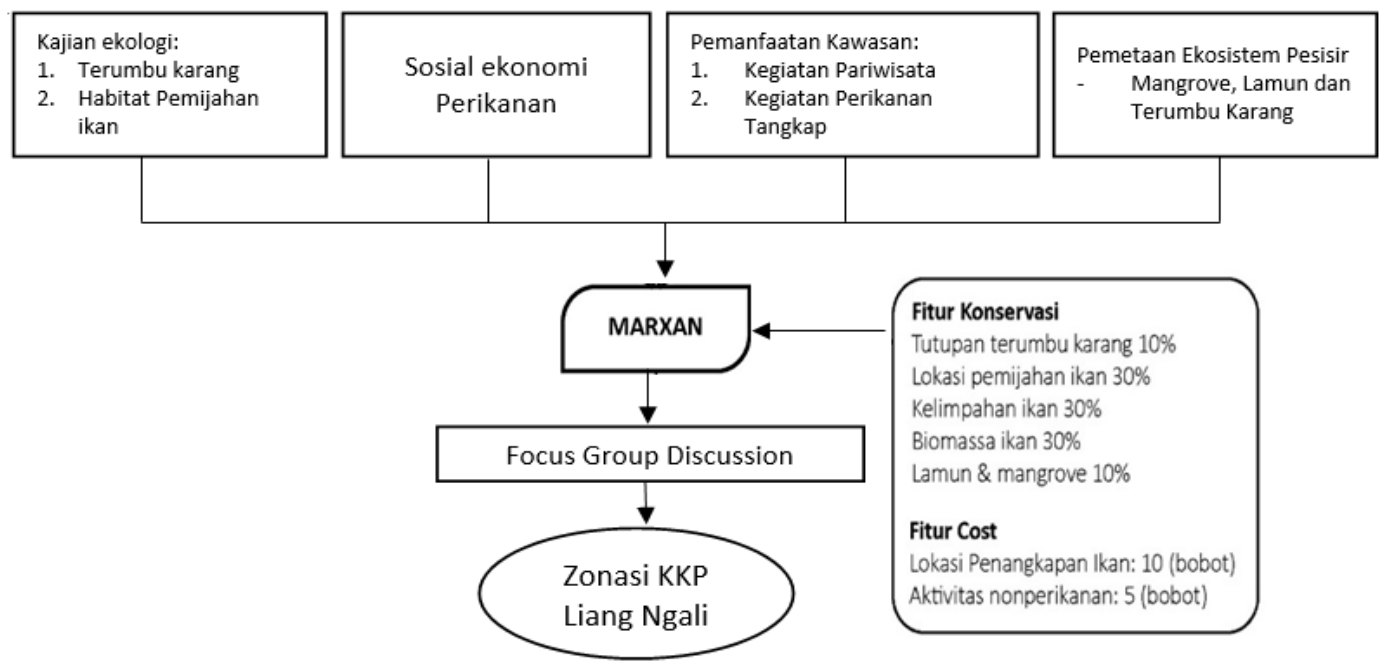

Gambar 2. Diagram alir proses penataan zonasi di KKP Pulau Liang dan Pulau Ngali

\section{HASIL DAN PEMBAHASAN}

\section{Pola Pemanfaatan KKP Pulau Liang dan Pulau Ngali}

Sebagian besar perairan Pulau Liang dan Ngali dimanfaatkan untuk kegiatan perikanan baik itu perikanan tangkap maupun budidaya (Gambar 3). Kegiatan perikanan tangkap di Perairan Pulau Liang dan Pulau Ngali dilakukan oleh nelayan dari Desa Labuhan Kuris yang tersebar di tiga dusun yaitu dusun Labuhan Terata, Dusun Labuhan Kuris dan Tanjung Bele. 


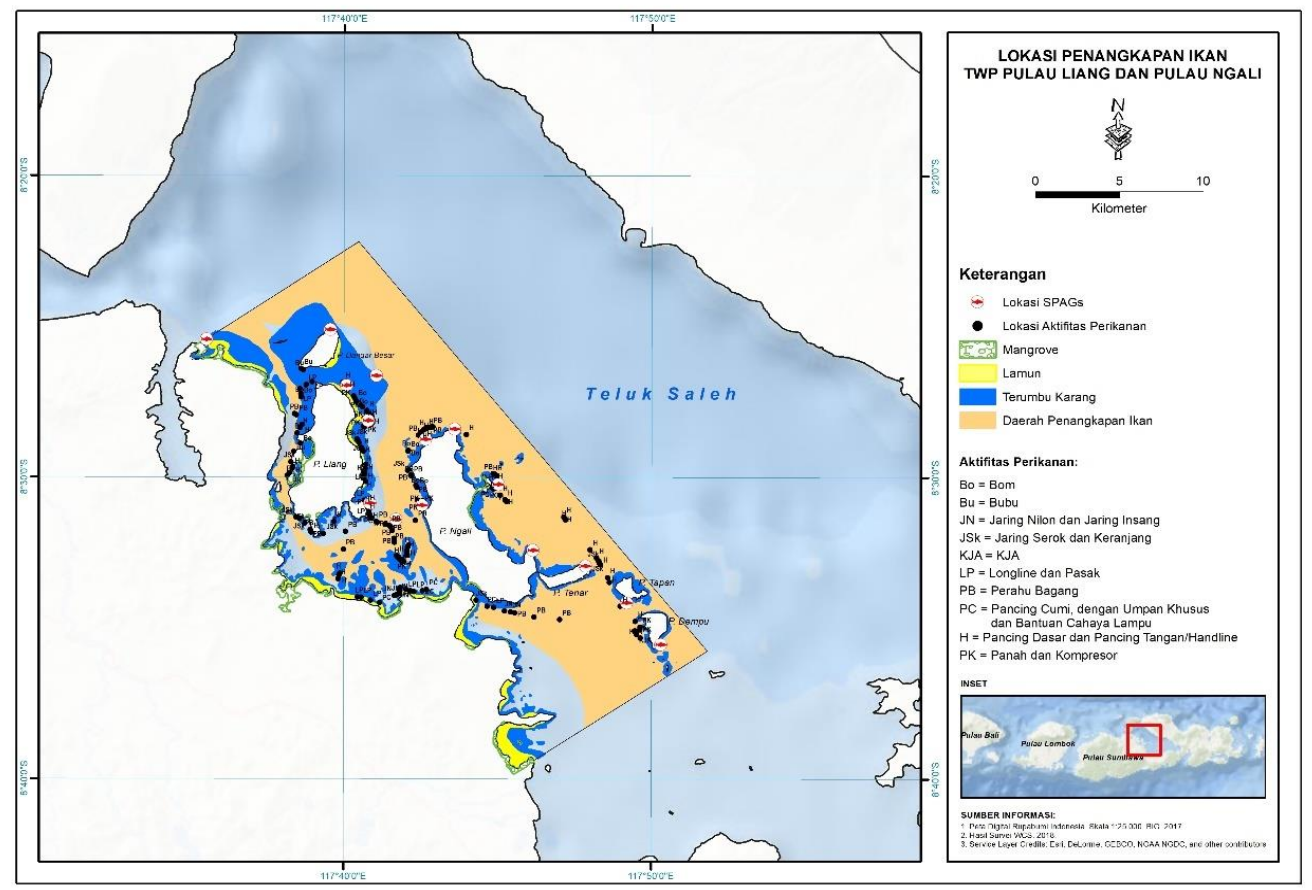

Gambar 3. Peta sebaran pemanfaatan perairan dan sebaran ekosistem pesisir di Pulau Liang dan Pulau Ngali

Armada penangkapan di KKP Pulau Liang dan Pulau Ngali mencapai 642 armada yang berasal dari tiga kecamatan dan lima desa (Gambar 4). Kecamatan Moyo Hilir memiliki armada yang lebih banyak dibandingkan dua kecamatan lainnya. Dari kelima desa yang ada, Desa Labuhan Sangoro dari Kecamatan Maronge memiliki jumlah armada yang paling banyak, yaitu mencapai 216 armada. Pada umumnya armada penangkapan di wilayah KKP Pulau Liang dan Pulau Ngali tidak memiliki perizinan karena ukurannya di bawah 5 GT.

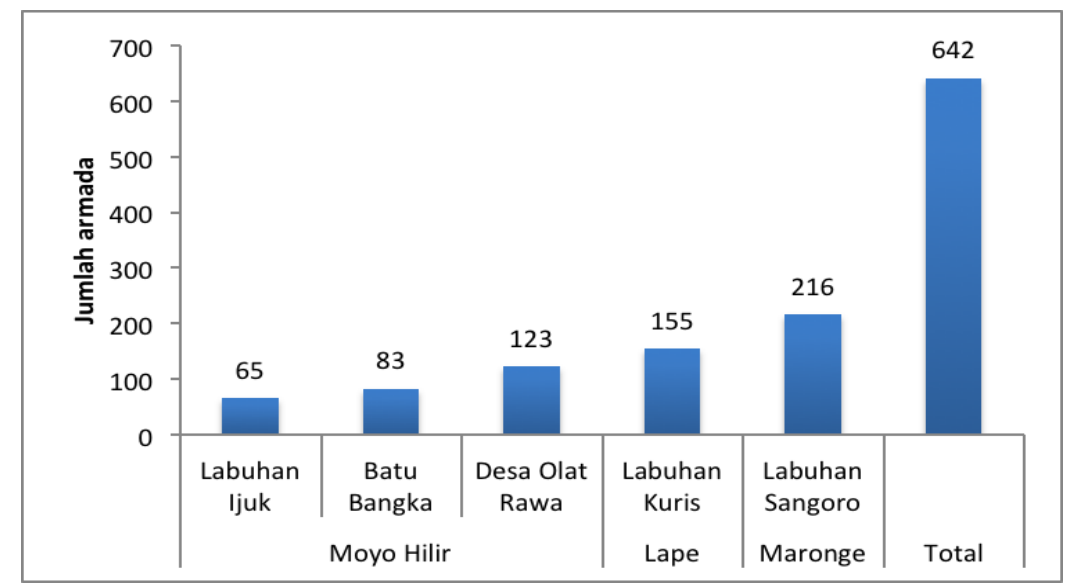

Gambar 4 Armada penangkapan ikan di KKP Pulau Liang dan Pulau Ngali

Berdasarkan kajian yang dilakukan, terdapat 8 jenis alat tangkap yang ada di KKP Pulau Liang dan Pulau Ngali antara lain jenis pancing, jaring, keramba, pancing dan kombinasi panah menggunakan alat bantu kompresor. Jenis hasil tangkapan nelayan di wilayah KKP Pulau Liang dan Pulau Ngali adalah ikan karang dan ikan pelagis. Ikan karang yang menjadi tangkapan utama adalah kakap (Lutjanidae), kerapu (Epinephelidae), ekor kuning (Caesionidae), ketambak (Lethrinidae), baronang (Siganidae), kuwe (Carangidae). Ikan pelagis yang menjadi tangkapan 
utama adalah tongkol (Euthynnus affinis), tenggiri (Scomberomorus commerson), tembang (Sardinella fimbriata), layang (Decapterus russelli) dan teri (Clupeidae). Secara umum sebagian besar ikan dapat ditangkap sepanjang tahun, namun hasil tangkapan akan bervariasi tergantung musim ikan tertentu.

Kegiatan budidaya yang berkembang di Perairan Pulau Liang dan Pulau Ngali yaitu budidaya kerang mutiara dan rumput laut. Budidaya mutiara banyak dilakukan di sebelah barat dan timur Pulau Liang dan bagian selatan Pulau Saroko. Kegiatan budidaya mutiara dilakukan oleh perusahaan-perusahaan swasta dan belum dilakukan oleh masyarakat pesisir. Hal ini disebabkan besarnya investasi usaha yang diperlukan serta belum dikuasainya teknologi budidaya mutiara oleh masyarakat pesisir.

\section{Pemetaan Ekosistem Pesisir}

Berdasarkan pengolahan data citra satelit menggunakan algoritma Lyzenga ditemukan luasan terumbu karang sebesar 8.141,12 Ha, padang lamun sebesar 234,81 Ha (hasil interpretasi citra tahun 2011), dan kawasan mangrove sebesar 8162,24 Ha (hasil interpretasi citra tahun 2009). Total luasan ekosistem pesisir yang berada di kawasan adalah 8.397,05 ha. Sebaran ekosistem padang lamun ditemukan di Pulau Dangar Ode, Pulau Liang dan Pesisir Desa Lape. Kawasan hutan mangrove tersebar di Pesisir Desa Moyo Hilir, Desa Lape, Desa Maronge dan Barat Pulau Liang. Sedangkan kawasan terumbu karang hampir tersebar di pesisir KKP Pulau Liang dan Pulau Ngali (Gambar 3).

\section{Kondisi Ekologis KKP Pulau Liang dan Pulau Ngali}

Keanekaragaman karang keras terdiri atas 16 famili dan 62 genera karang keras, berasal dari famili Faviidae sebanyak 14 genera, Fungiidae sebanyak 10 genera, Mussidae sebanyak 6 genera, Acroporidae sebanyak 5 genera dan Agariciidae sebanyak 5 genera dan 22 genera masuk di family lainnya. Keanekaragaman jenis ikan karang di KKP Pulau Liang dan Pulau Ngali terdiri atas 29 famili, 88 genus dan 201 jenis, berasal dari famili Pomacentridae (betok laut) sebanyak 71 jenis, Labridae (keling-kelingan), termasuk jenis ikan dari sub-famili Scarini sebanyak 70 jenis, diikuti oleh Acanthuridae (butana) sebanyak 27 jenis, dan Chaetodontidae (kepe-kepe) sebanyak 26 jenis, sedangkan 7 jenis lainnya masuk di family lainnya. Keanekaragaman ikan karang tertinggi ditemukan pada lokasi Ngali W dengan jumlah spesies ikan sebanyak 119 spesies, sedangkan keanekaragaman spesies ikan terendah ditemukan pada lokasi Liang N dan Liang S2 dengan jumlah spesies ikan masing-masing sebanyak 52 spesies. Keragaman genus terumbu karang tertinggi ditemukan pada lokasi Liang $\mathrm{N}$ dengan jumlah genera sebanyak 73 genera, sedangkan keanekaragaman genera terendah ditemukan pada lokasi Ngali E dengan jumlah genera sebanyak 7 genera. Kepadatan kima tertinggi ditemukan pada lokasi Ngali W dengan nilai kepadatan sebesar 3000 no.ha $^{-1}( \pm 177,95 \mathrm{SE})$ dan kepadatan kima terendah ditemukan pada lokasi Liang W dengan kepadatan sebesar 75 no.ha-1 $( \pm$ 47,87 SE; Gambar 5)

Rata-rata tutupan karang di KKP Pulau Liang dan Pulau Ngaliadalah 50\% dengan kategori baik ([MENLH] Menteri Negara Lingkungan Hidup 2001) berdasarkan KepMen LH No 4 Tahun 2001 tentang Kriteria Baku Kerusakan Terumbu Karang. Tutupan karang paling tinggi terletak di lokasi Liang S1 dengan tutupan karang sebesar 70,5 \% ( \pm 35,25 SE), sedangkan tutupan karang paling rendah terletak di lokasi Pulau Liang sebelah barat sebesar 30,5\% ( \pm 35,25 SE; Gambar 6A). Genera karang keras Porites merupakan genera karang keras yang mendominasi di wilayah KKP Pulau Liang dan Pulau Ngali dengan tutupan 51,33\%, kemudian disusul oleh genera karang Acropora 16,33\%, Pavona 9,5\% dan Montipora 4,67\%. Sedangkan, Rata-rata karang rekrut di 
KKP Pulau Liang dan Pulau Ngaliadalah 3,81 no. $\mathrm{m}^{-2}( \pm 0,55$ SE). Karang rekrutment paling tinggi terletak di lokasi Ngali $\mathrm{N}$ dengan nilai karang rekrut sebesar 6,66 no.m $\mathrm{m}^{-2}( \pm 1,21 \mathrm{SE})$, sedangkan karang rekrut paling rendah terletak di lokasi Dangar Ode dengan nilai sebesar 1,33 no. $\mathrm{m}^{-2}( \pm 0,52$ SE; Gambar 6B). Perairan Pulau Liang dan Pulau Ngali merupakan perairan teluk semi tertutup yang tenang dan cenderung berarus kecil dengan rata-rata kelimpahan yaitu 13.313,22 no.ha- ${ }^{1}$ ( \pm 977,54 SE). Kelimpahan ikan karang tertinggi terletak di lokasi Ngali N dengan nilai 18.635 no.ha $^{-1}( \pm 2.651,57, \mathrm{SE})$ sedangkan kelimpahan terendah terletak di Ngali E dengan nilai 9.670 no.ha $^{-1}( \pm 1.275,99$ SE) (Gambar 6C). Ikan dari famili Pomacentridae merupakan ikan dengan kelimpahan tertinggi. Rata-rata biomassa ikan karang di KKP Pulau Liang dan Pulau Ngali adalah 344,57 kg.ha- ${ }^{-1}( \pm 31,21 \mathrm{SE})$ (Gambar 5D). Biomassa ikan tertinggi di temukan di lokasi Ngali N sebesar 503,96 kg.ha- ${ }^{1}$ ( \pm 96,75 SE) sedangkan terendah di lokasi Liang W sebesar 216.34 kg.ha${ }^{1} \pm 40,50$ SE. Ikan dari famili Pomacentridae merupakan ikan dengan biomassa tertinggi.

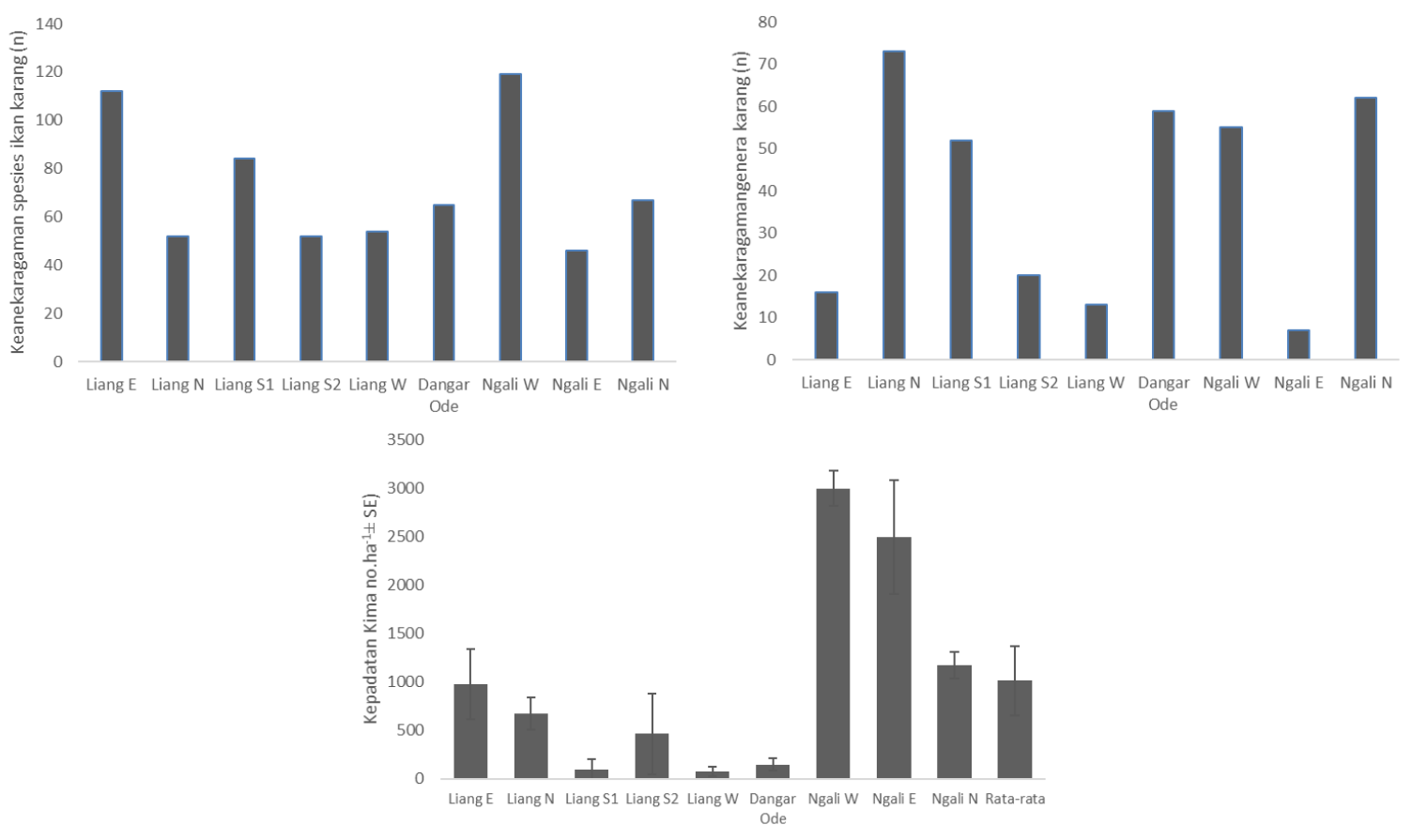

Gambar 5. Keanekaragamn spesies ikan (n), Keanekaragaman genera karang (n) dan kepadatan kima (no.100 m-2 \pm SE) di KKP Pulau Liang dan Pulau Ngali (note: konsistensi penulisan nama KKP 

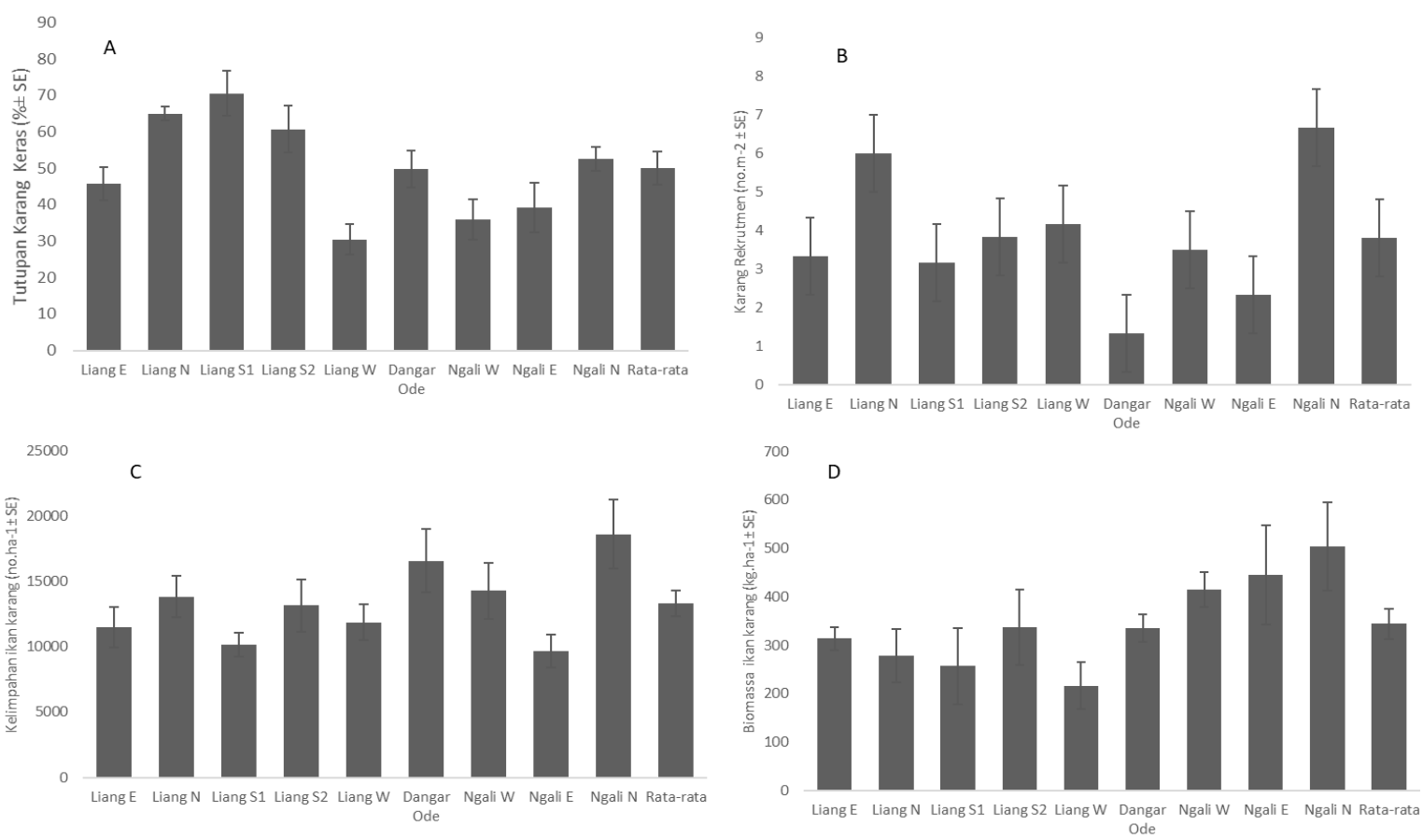

Gambar 6. Tutupan karang keras (\% \pm SE; A), kepadatan rekrutmen (no.m-2 \pm SE; B),

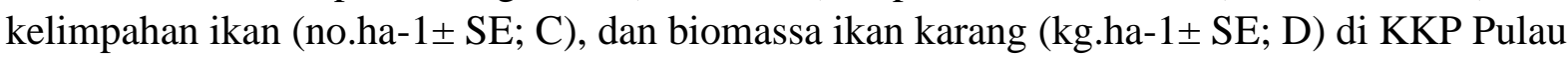
Liang dan Pulau Ngali

\section{Lokasi Pemijahan Ikan Karang}

Pulau Liang dan Pulau Ngali juga diindikasikan sebagai lokasi pemijahan ikan karang khususnya jenis kerapu dan kakap. Pengamatan dilakukan pada 15 titik di sekitar KKP Pulau Liang dan Pulau Ngali (Gambar 7). Berdasarkan kajian ditemukan 6 genus dan 21 spesies ikan kerapu (famili Ephinephelidae) serta 2 genus dan 15 spesies ikan kakap (family Lutjanidae). Dari 36 spesies kakap dan kerapu tersebut, 16 spesies diindikasikan melakukan pemijahan dengan ciri berkelompok (aggregation), berpasangan (courthship) dan perwarnaan. Spesies tersebut adalah Lutjanus biguttatus, Lutjanus bohar, Lutjanus carponotatus, Lutjanus ehrenbergii, Lutjanus fulviflamma, Lutjanus kasmira, Lutjanus lutjanus, Macolor macularis dan Lutjanus qunquelineatus yang berasal dari famili Lutjanidae dan Anyperodon leucogramicus, Cephalopholis boenack, Epinephelus fasciatus, Epinephelus spilotoceps, Plectropomus leopardus, Plectropomus maculatus dan Plectropomus oligacanthus yang berasal dari famili Ephinephelidae.

Berdasarkan hasil perhitungan menggunakan empat parameter ekologis yakni jumlah individu per spesies, selang ukuran ikan karang, tanda-tanda pemijahan, dan biota karismatik didapatkan 3 kategori baik yang ditandai dengan warna hijau, sedang yang ditandai dengan warna kuning dan buruk yang ditandai dengan warna merah. Lokasi-lokasi yang menunjukkan indikasi kuat sebagai lokasi SPAGs (hijau) adalah Pulau Putri, Tanjung Labuan Aji, Tanjung Ngali, Tanjung Tete, dan Teluk Buluh. Pada lokasi-lokasi tersebut selang kelas ukuran ikan didominasi oleh ukuran 15-25 cm. Indikasi tanda-tanda pemijahan seperti berkelompok, berpasangan dan perubahan warna ditemukan pada seluruh lokasi tersebut. 


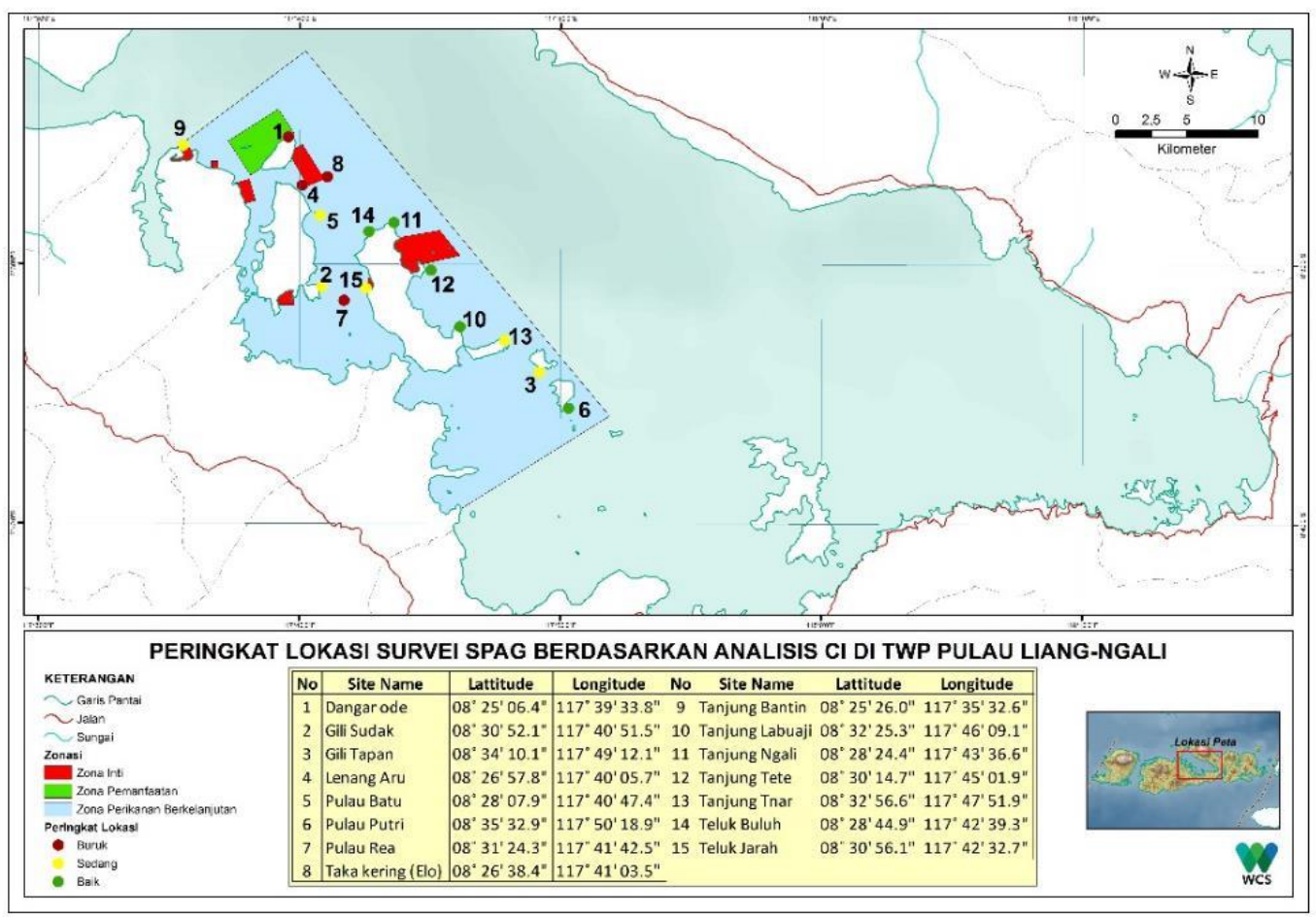

Gambar 7. Lokasi survey tempat pemijahan ikan di KKP Pulau Liang dan Pulau Ngali

\section{Penataan zonasi di KKP Pulau Liang Pulau Ngali}

Hasil analisis Marxan berdasarkan fitur konservasi dan fitur costmenghasilkan lokasi prioritas yaitu lokasi yang berpotensi untuk dijadikan daerah perlindungan. Setelah lokasi prioritas teridentifikasi, analisis dilanjutkan dengan pemilihan kawasan berdasarkan prinsip 3K, yaitu keterwakilan, keterulangan dan konektivitas.

Fitur konservasi yang digunakan yaitu keberadaan ekosistem mangrove, lamun dan terumbu karang. Hasil dari lokasi prioritas kemudian disampaikan pada proses konsultasi publik di tingkat desa, kabupaten dan provinsi dengan tujuan mendapatkan masukan dan kesepakatan zonasi yang terpilih sebagai lokasi larang tangkap di KKP Pulau Liang dan Pulau Ngali.

Penataan zonasi KKP Pulau Liang dan Pulau Ngali telah melalui beberapa pertemuan tim kelompok kerja (pokja) dan konsultasi publik. KKP Pulau Liang Ngali diberi nama Taman Wisata Perairan menurut Surat Penetapan oleh Menteri Kelautan dan Perikanan Republik Indonesia nomor 20 tahun 2020. Kawasan ini terbagi menjadi zona inti, pariwisata, perikanan berkelanjutan dan rehabilitasi (Gambar 8).

Zona inti diperuntukkan bagi perlindungan mutlak habitat dan populasi ikan, perlindungan ekosistem pesisir yang unik dan atau rentan terhadap perubahan, penelitian dan pendidikan. Kegiatan perlindungan mutlak habitat dan populasi ikan meliputi: perlindungan proses ekologis; penjagaan dan pencegahan dari kegiatan yang dapat mengakibatkan gangguan terhadap ekosistem dan perubahan fungsi kawasan, keutuhan potensi kawasan dan perubahan fungsi kawasan dan/atau pemulihan dan rehabilitasi ekosistem, serta perlindungan alur migrasi biota laut. Zona ini memiliki luasan sebesar 1407 ha atau setara dengan 4.29\% dari luas total kawasan KKP Liang Ngali Yakni 32.835 ha dengan penetapan pelarangan kegiatan pemanfaatan.

Zona Pemanfaatan merupakan bagian kawasan konservasi perairan yang letak, kondisi, dan potensi alamnya diutamakan untuk kepentingan perlindungan dan pelestarian habitat dan populasi ikan; pariwisata dan rekreasi; penelitian dan pengembangan; dan pendidikan. Kegiatan pariwisata 
dan rekreasi yang diperbolehkan meliputi: rekreasi pantai, menyelam; pariwisata jasa lingkungan seperti snorkeling dan menggunakan perahu kaca (glass bottom boat); banana boat; pariwisata minat khusus; perahu pariwisata; olahraga permukaan air seperti berenang, selancar air (surfing), dayung/kayak dan jenis olahraga air lainnya. Zona ini memiliki luasan sebesar 1422,51 ha atau setara dengan 4.33\% dari luas total kawasan KKP Liang Ngali Yakni 32.835 ha dengan penetapan pelarangan kegiatan pemanfaatan.

Zona Perikanan Berkelanjutan adalah bagian kawasan konservasi perairan yang karena letak, kondisi dan potensinya mampu mendukung kepentingan pelestarian pada zona inti dan zona pemanfaatan. Zona ini memiliki luasan sebesar 29248.32ha atau setara dengan $89.08 \%$ dari luas total kawasan KKP Liang Ngali yakni 32.835 ha dengan penetapan pelarangan kegiatan pemanfaatan.

Sedangkan zona rehabilitasi memiliki luasan 757,88 ha atau setara dengan $2.31 \%$ dari luas total kawasan KKP Liang Ngali yakni 32.835 ha dengan penetapan kegiatan pemanfaatan dan diperuntukkan sebagai lokasi rehabilitasi ekosistem pesisir.

Secara umum lokasi pelarangan kegiatan pemanfaatan atau no take area telah melindungi 3 jenis ekosistem penting yakni lamun, terumbu karang dan mangrove yang berada di zona inti dan pemanfaatan dengan luas sebesar 1.842,35 ha atau setara dengan 5,61\% dari luas kawasan KKP Liang Ngali.

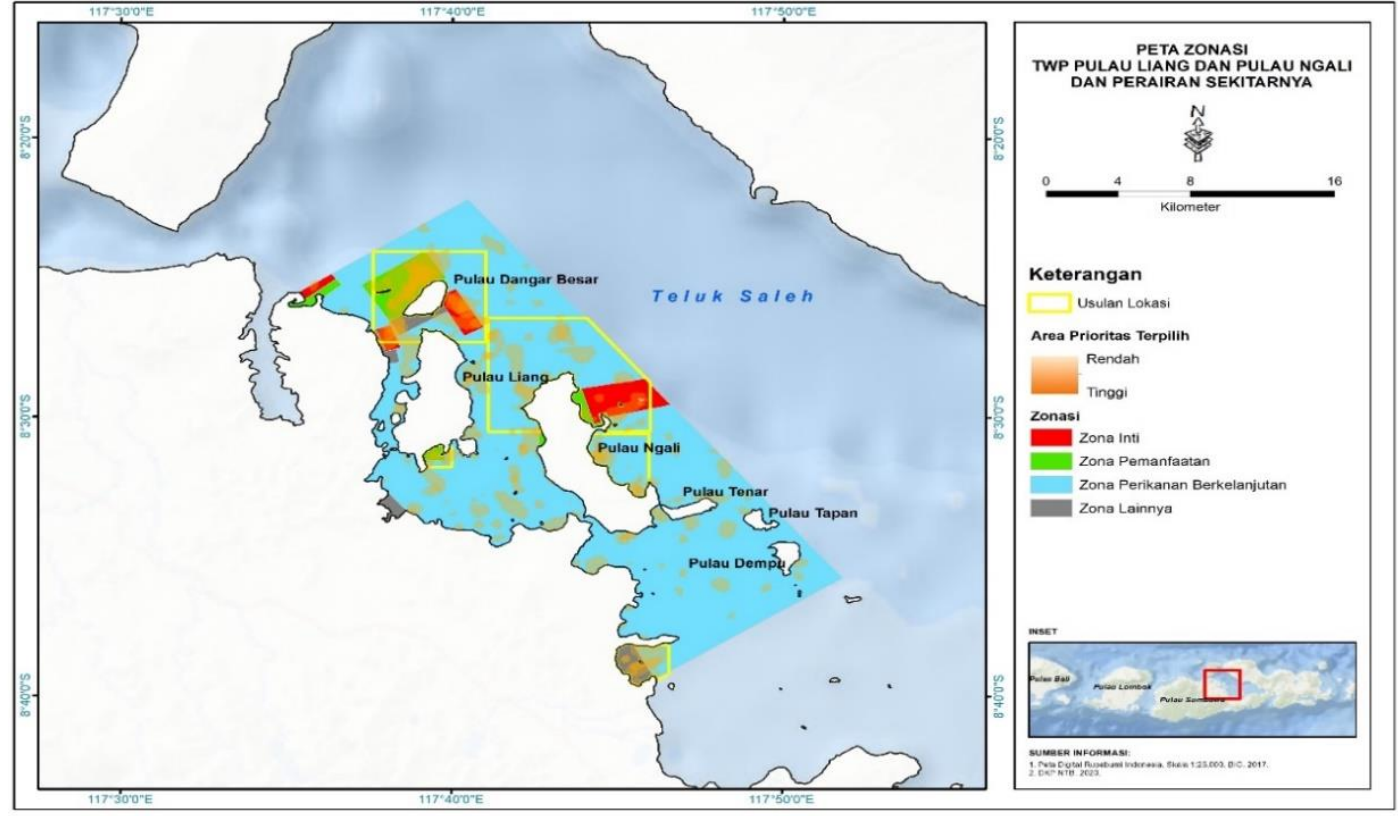

Gambar 8.. Peta Zonasi KKP Pulau Liang dan Pulau Ngali

\section{PEMBAHASAN}

Menurut Green et al., (2014) kriteria dan desain MPA untuk tujuan pengelolaan perikanan berkelanjutan harus memiliki keterwakilan sebanyak 20-40\% dari setiap habitat utama seperti terumbu karang, hutan bakau, dan komunitas lamun. Hal ini bertujuan agar setiap spesies yang berbeda dapat menggunakan habitat untuk makanan, tempat tinggal, dan bereproduksi.

Selain itu, penting untuk melindungi area yang telah menunjukkan kelangsungan hidup atau pemulihan yang baik dari waktu ke waktu, melindungi area kritis, khusus, dan unik seperti area pemijahan ikan, area perkembangbiakan, dan area untuk mencari makan spesies yang menjadi target konservasi di dalam kawasan (termasuk spesies perikanan kunci, herbivora dan spesies langka dan terancam misalnya, kura-kura, duyung dan cetaceans) dengan cara pelarangan aktifitas 
penangkapan dan aktifitas wisata lokasi tersebut.

Pada tahap proses penataan zonasi, KKP Pulau Liang dan Pulau Ngali telah mengalokasikan luasan ekosistem pesisir (mangrove, lamun dan terumbu karang) sebagai lokasi larang tangkap dengan luas area sebesar adalah 1842,35 ha atau setara dengan $21.94 \%$ dari luas keseluruhan ekosistem pesisir yang masuk ke dalam KKP Liang Ngali.

Secara ekologis, yang termasuk lokasi penting antara lain habitat pemijahan ikan, lokasi yang memiliki kelimpahan dan biomassa ikan herbivora tinggi, lokasi memiliki kepadatan rekrutment karang yang baik. Lokasi ini kemudian dijadikan sebagai lokasi larang tangkap, seperti di lokasi penelitian Ngali. Dengan penerapan aturan tersebut diharapkan dapat menjaga kondisi ekosistem pesisir sehingga dapat memberikan kesempatan untuk spillover spesies ikan dewasa dan juga spesies ikan larva dan ikan juvenile ke wilayah luar zona larang tangkap.

Untuk menjaga stok perikanan agar dapat dipanen secara berkelanjutan, sehingga memberikan manfaat sosial ekonomi kepada masyarakat pesisir dalam mencapai tujuan tersebut, maka pengelolaan kolaboratif menjadi penting. Kerjasama antar pemerintah dan masyarakat banyak diterapkan dalam pengelolaan kawasan, dimulai dari penentuan lokasi kawasan konservasi hingga dalam penerapan pengelolaan kawasan konservasi.

Beberapa contoh pendekatan kolaboratif diterapkan oleh negara-negara tetangga, seperti di Asia Tenggara seperti di Malaysia, Indonesia dan Filipina yang menerapkan kerjasama antara pemerintah dengan masyarakat (Campbell et al. 2013); (Cabigas and Manzano 2012) (Yulianto et al. 2015) (Rahman et al. 2019) melalui partisipasi aktif penggunaan sumber daya terutama untuk membentuk aturan pengelolaan bersama, baik di tingkat pemerintah maupun di tingkat masyarakat. Beberapa dampak dari kegiatan kolaborasi tersebut adalah perbaikan stok sumberdaya ikan-ikan terutama untuk jenis perikanan karang yakni kerapu, kakap, ekor kuning dan serta perbaikan tutuan karang keras. Sedangkan beberapa kawasan konservasi laut yang berada di Samudera Hindia bagian barat menunjukan bahwa dengan melalui jaringan pengelolaan masyarakat lokal akan memberikan dampak seperti meningkatnya biomassa ikan dibandingkan dengan kawasan yang tidak memiliki pengelolaan masyarakat lokal (Rocliffe et al, 2014). Selain itu pengelolaan kolaborasi ini harus didukung juga keseimbangan dan integrasi yang baik antara pendekatan bottom-up dan top-down dengan mempertimbangkan skala dari kawasan konservasi laut, skenario geografis, tingkat pengaruh antropogenik, tujuan konservasi, konteks politik, dan tata kelola serta kondisi budaya tertentu seperti komunitas adat (Gaymer et al. 2014).

Berdasarkan pembelajaran tersebut, strategi pengelolaan kolaboratif menjadi contoh model pengelolaan yang dapat diterapkan di kawasan konservasi Pulau Liang dan Ngali. Pengelolaan kolaboratif ini dilaksanakan dengan melibatkan seluruh pemangku kepentingan yang ada mulai dari masyarakat, pemerintah, akademisi, lembaga swadaya serta pelaku usaha wisata dan perikanan. Beberapa strategi pengelolaan kolaboratif yang coba diterapkan dalam konteks penerapan pengelolaan kawasan konservasi antara lain penguatan kelembagaan masyarakat, kegiatan monitoring dan evaluasi kawasan, menyusun aturan pengelolaan bersama di tingkat masyarakat, kerjasama kemitraan, kampanye dan penyadartahuan, kegiatan pemantauan dan pengawasan, pengembangan sarana dan prasarana pengelolaan, dan kegiatan rehabilitasi ekosistem.

Penguatan kelembagaan di tingkat masyarakat bertujuan melibatkan partisipasi aktif masyarakat dalam membantu pelaksanaan program pengelolaan kawasan di KKP Pulau Liang dan Pulau Ngali. Upaya ini dilakukan dengan cara pembinaan kelompok masyarakat serta peningkatan kapasitas masyarakat dalam melakukan kegiatan pemantauan dan pengawasan. Di dalam tahap implementasinya, target yang disasar dari kegiatan ini adalah sosialisasi terkait peraturan zonasi kepada nelayan, serta pengawasan sumberdaya dari kegiatan yang merusak ekosistem terumbu 
karang serta patroli rutin bersama aparat di sekitar kawasan konservasi perairan. Menurut studi yang dilakukan oleh Asri (2019) di Taman Nasional Takabonerate kerjasama antar instansi dalam pengawasan dan penindakan pelaku praktik perikanan destruktif pada kawasan merupakan salah satu cara bagaimana mengatasi permasalahan kegiatan perikanan destruktif. Kerjasama ini termasuk bagaimana mengidentifikasi jaringan pasar bahan baku bom dan bius ikan serta pemasaran ikan hasil praktik perikanan destruktif. Di samping itu juga diperlukan program pendampingan kepada nelayan untuk memutus kuatnya hubungan patron-klienpunggawa-sawidan mengupayakan mengaktifkan kembali kelembagaan lokal Panglima Laut dalam pengelolaan sumberdaya perikanan tangkap yang ramah lingkungan di kawasan tersebut (Asri, Wahyuni, and Satria 2019).

Kegiatan monitoring target konservasi kawasan bertujuan untuk mengevaluasi kondisi target konservasi di dalam kawasan, yakni status stok perikanan karang (kakap dan kerapu), kondisi ekosistem pesisir (mangrove, lamun dan terumbu karang) serta sosial ekonomi masyarakat pesisir. Salah satu contoh penerapan hasil kajian monitoring adalah bagaimana penerapan pengelolaan adaptif bisa dilaksanakan. Hasil optimal dapat dicapai jika nilai-nilai manajemen, pemantauan dan pemicu didefinisikan sebelum dimulainya suatu program (Gerber et al. 2005).

Menyusun aturan pengelolaan bersama di tingkat masyarakat merupakan salah satu cara pengendalian dan pemanfaatan sumber daya ikan yang ada di kawasan. Dengan adanya aturan yang dibuat dan disepakati bersama oleh masyarakat diharapkan akan mampu meningkatkan rasa kepemilikan bersama terhadap sumberdaya serta meningkatkan partisipasi keterlibatan masyarakat terhadap aturan yang dibuat sehingga akan memberikan dampak terhadap perbaikan ukuran panjang ikan serta melindungi habitat penting dimana ikan tersebut mencari makan, memijah dan berlindung.

Model kerjasama kemitraanakan memperkuat unit pengelola dalam pengelolaan kawasan di KKP Pulau Liang dan Pulau Ngali. Kerjasama yang dilakukan diharapkan dapat mengatasi kesenjangan sumberdaya manusia, pendanaan kawasan konservasi perairan serta mendukung beragam peluang pendapatan seperti usaha kecil, pertanian, perikanan, pertanian rumput laut, pariwisata, sehingga dapat membantu mengurangi ketergantungan masyarakat terhadap sumber daya laut. Kerjasama kemitraan ini dapat melibatkan unit pengelola seperti universitas, masyarakat, Lembaga Swadaya Masyarakat dan pelaku usaha sehingga akan membantu dalam implementasi pengelolaan seperti kegiatan penelitian, penyuluhan dan pelatihan, peningkatan dan pemasaran produk hasil hasil perikanan pengembangan kegiatan usaha wisata berbasis masyarakat dan pengembangan pendanaan berkelanjutan berbasis masyarakat

Sebagai contoh, beberapa pendekatan kerjasama kemitraan dirasakan berhasil seperti di wilayah pengelolaan kawasan konservasi Raja Ampat dimana salah satu cara mengatasi pendanaan berkelanjutan adalah dengan dibentuknya mekanisme pendanaan "Blue Abadi Fund". Sedangkan untuk pendanaan berskala kecil juga dilakukan di kawasan konservasi perairan TWP Gili SulatLawang dimana pada mekanisme ini dilaksanakan pembagian hasil usaha pariwisata untuk mendukung kegiatan pemantauan dan pengawasan setiap bulannya (Hernawati et al. 2018). Dukungan pemerintah dan swasta terutama untuk aspek keuangan diperlukan untuk keberhasilan tidak hanya kondisi ekologi tetapi juga memberikan lebih banyak manfaat bagi masyarakat (Cabigas and Manzano 2012).

Kegiatan kampanye dan penyadartahuan bertujuan untuk mensosialisasikan fungsi zona larang tangkap sebagai lokasi pelarangan aktifitas pengambilan hasil tangkapan serta mensosialisasikan kegiatan yang boleh dan tidak boleh pada setiap zona yang ada di kawasan dan target konservasi kawasan. Rehabilitasi pesisir dilakukan guna menjaga dan melindungi target konservasi di dalam kawasan. Secara rinci, strategi pengelolaan KKP Pulau Liang dan Pulau Ngali

Lesser Sunda 1(2): 26-43, Juli 2021 
disajikan pada Gambar 9.

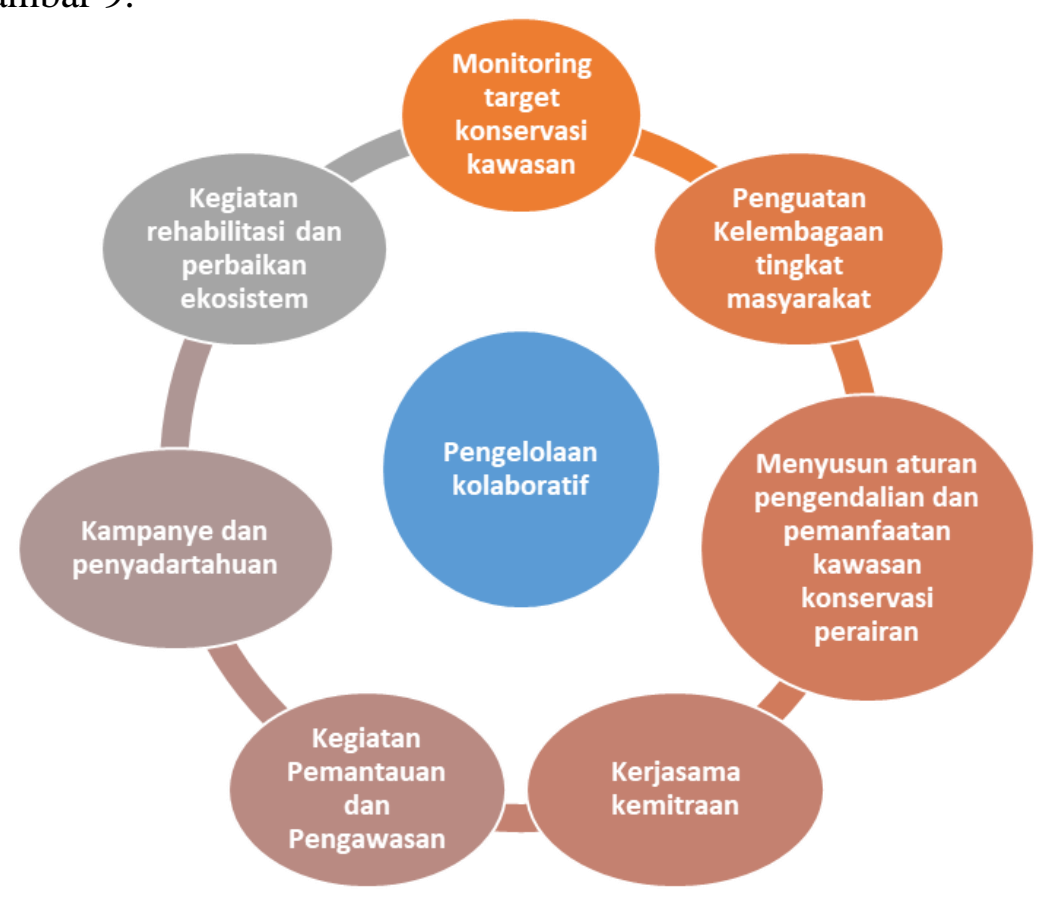

Gambar 9. Strategi pengelolaan kawasan konservasi di Pulau Liang dan Ngali

\section{KESIMPULAN}

Pulau Liang dan Ngali merupakan salah satu kawasan konservasi yang memiliki potensi sumberdaya perikanan yang perlu dijaga dan dilindungi agar tujuan dan pemanfaatan sumberdaya perikanan di dalam kawasan tersebut dapat memberikan kesejahteraan kepada masyarakat pesisir yang tinggal dan memanfaatkan sumberdaya di dalam kawasan tersebut.

Dalam merancang sebuah kawasan konservasi perairan perlu melakukan kajian terhadap berbagai aspek seperti aspek ekologi, sosial, ekonomi, budaya, dan pola pemanfaatan kawasan. Aspek ekologi meliputi kondisi mangrove, lamun, terumbu karang, tutupan karang keras, kelimpahan ikan karang, biomassa ikan karang, kepadatan rekrutment karang, kepadatan makro invertebrata penting (kima), kekayaan spesies ikan karang, kekayaan genera terumbu karang, dan habitat pemijahan ikan karang. Pola pemanfaatan kawasan meliputi kegiatan perikanan tangkap dan perikanan budidaya.

Data tersebut kemudian diolah menggunakan analisis marxan untuk melihat kesesuaian pola pemanfaatan ruang dengan zonasi yang akan dibentuk sehingga dapat mencapai tujuan konservasi. Berdasarkan hasil analisis yang telah dilakukan, dihasilkan zonasi di KKP Pulau Liang dan Pulau Ngali yang terdiri atas empat zona yaitu zona inti, pemanfaatan pariwisata, perikanan berkelanjutan dan zona lainnya yang diperuntukkan sebagai subzone rehabilitasi. Setelah data dan informasi dikumpulkan pelibatan dan partisipasi aktif masyarakat diperlukan guna memberikan pendapat dan masukan terhadap penataan zonasi di KKP Liang Ngali. Sementara dalam rangka mencapai tujuan jangka panjang yakni pengelolaan sumberdaya perikanan yang berkelanjutan dan kesejahtraan masyarakat, maka strategi pengelolaan kolaboratif merupakan salah satu pendekatan yang dapat diimplementasikan.

\section{DAFTAR PUSTAKA}

[MENLH] Menteri Negara Lingkungan Hidup. 2001. Keputusan Menteri Negara Lingkungan Hidup No 
. 4 Tahun 2001 Tentang: Kriteria Baku Kerusakan Terumbu Karang. Indonesia: Keputusan Menteri Negara Lingkungan Hidup.

Ardron, J.A., H.P. Possingham, and C.J. Klein. 2010. "Marxan Good Practices Handbook, Version 2." Pacific Marine Analysis and Research Association, no. June: 165. www.pacmara.org.

Asri, Muh, Ekawati Sri Wahyuni, and Arif Satria. 2019. "Destructive Fishing Practices (Case Study on the Taka Bonerate National Park)." Sodality: Jurnal Sosiologi Pedesaan, no. Puspito 2010: 25-33.

Cabigas, Brando, and Lawrence Manzano. 2012. "Success and Failure of Marine Protected Area Management Affecting the Fish Catch by Adjacent Fishermen in Sarangani Bay , Mindanao , Philippines."

Campbell, Stuart J., Tasrif Kartawijaya, Irfan Yulianto, Rian Prasetia, and Julian Clifton. 2013. "CoManagement Approaches and Incentives Improve Management Effectiveness in the Karimunjawa National Park, Indonesia." Marine Policy 41: 72-79. https://doi.org/10.1016/j.marpol.2012.12.022.

Colin, Patrick L. 2006. "Study of Reef Fish Spawning Aggregations and Connectivity on the Palauan Reef Tract Final," no. 2.

DKP NTB. 2018. "Rencana Pengelolaan Dan Zonasi Taman Wisata Perairan Pulau Liang Dan Pulau Ngali."

Freudenberger, Karen Schoonmaker. 1999. Rapid Rudal Appraisal and Participatory Rural Apraisal : A Manual for CRS Field Workers and Partners. Baltimore, Maryland: Catholic Relief Services (CRS). $\quad$ https://www.crs.org/sites/default/files/tools-research/rapid-rural-appraisal-andparticipatory-rural-appraisal.pdf.

Game, Edward T, Hedley S Grantham, Hedley S Grantham, Carissa Klein, Carissa Klein, Dave Nicolson, Dave Nicolson, et al. 2008. "Marxan User Manual: For Marxan.” Analysis, 127.

Gaymer, Carlos F., Angela V. Stadel, Natalie C. Ban, P. Francisco Cárcamo, Joseph Ierna, and Louise M. Lieberknecht. 2014. "Merging Top-down and Bottom-up Approaches in Marine Protected Areas Planning: Experiences from around the Globe." Aquatic Conservation: Marine and Freshwater Ecosystems 24 (S2): 128-44. https://doi.org/10.1002/aqc.2508.

Gerber, Leah R., Maria Beger, Michael A. McCarthy, and Hugh P. Possingham. 2005. "A Theory for Optimal Monitoring of Marine Reserves." Ecology Letters 8 (8): 829-37. https://doi.org/10.1111/j.1461-0248.2005.00784.x.

Green, Alison L., Leanne Fernandes, Glenn Almany, Rene Abesamis, Elizabeth McLeod, Porfirio M. Aliño, Alan T. White, Rod Salm, John Tanzer, and Robert L. Pressey. 2014. "Designing Marine Reserves for Fisheries Management, Biodiversity Conservation, and Climate Change Adaptation." Coastal Management 42 (2): 143-59. https://doi.org/10.1080/08920753.2014.877763.

Gurney, Georgina G., and Emily S. Darling. 2017. A Global Social-Ecological Systems Monitoring Framework for Coastal Fisheries Management.

Hernawati, Hernawati, Baiq Ida Purnawati, IDG Warmadewa, Eko Saputro, S.A.R Tarigan, Abdul Muis, Sebastian Aviandhika, Haerul Hazmi, and Fajar Ardiansyah. 2018. Implementasi Mekanisme Pendanaan Berkelanjutan Di Kawasan Konservasi Perairan Nusa Tenggara Barat. Studi Kasus : Taman Wisata Perairan Gita Nada Dan Gili Sulat Lawang. Edited by Wildife Conservation Society. Wildlife Conservation Society. Mataram: Wildife Conservation Society.

Hill, Josh, and Clive Wilkinson. 2004. Methods for Ecological Monitoring of Coral Reefs. Australian Institute of Marine Science, Townsville. https://doi.org/10.1017/CBO9781107415324.004.

Lester, Sarah E., Benjamin S. Halpern, Kirsten Grorud-Colvert, Jane Lubchenco, Benjamin I. Ruttenberg, Steven D. Gaines, Satie Airamé, and Robert R. Warner. 2009. "Biological Effects within No-Take Marine Reserves: A Global Synthesis." Marine Ecology Progress Series 384 (May): 33-46. https://doi.org/10.3354/meps08029. 
Morris, Annalie, Callum Roberts, and Julie Hawkins. 2000. "The Threatened Status of Groupers (Epinephelinae)." Biodiversity and Conservation 9 (November): 919-42. https://doi.org/10.1023/A.

Rafandi, Tezar, Adi Mihardja, Hernawati, Sebastian Aviandhika, I Made Dharma Jaya Aryawan, Eko Saputro, Abdul Muis, and Tasrif Kartawijaya. 2017. "Kajian Pemetaan Kegiatan Destructive Fishing Di Provinsi Nusa Tenggara Barat.” Mataram.

Rahman, Mohd Ashraf Abdul, Farahdilah Ghazali, Mohd Hazmi Mohd Rusli, Nazli Aziz, and Wan Izatul Asma Wan Talaat. 2019. "Marine Protected Areas in Peninsular Malaysia: Shifting from Political Process to Co-Management." Journal of Politics and Law 12 (4): 22. https://doi.org/10.5539/jpl.v12n4p22.

Setiawan, Fakhrizal, S.A.R Tarigan, Shinta Pardede, Tezar Rafandi, Bahaudin, and Azhar Muttaqin. 2017. "Laporan Teknis Identifikasi Lokasi Pemijahan Ikan (SPAGS) Dan Lokasi Penting Lainnya Di Taman Wisata Perairan Pulau Liang Dan Pulau Ngali Teluk Saleh, Provinsi Nusa Tenggara Barat." https://doi.org/10.1017/CBO9781107415324.004.

Yulianto, Irfan, Cornelius Hammer, Budy Wiryawan, and Harry W. Palm. 2015. "Fishing-Induced Groupers Stock Dynamics in Karimunjawa National Park, Indonesia." Fisheries Science 81 (3): 417-32. https://doi.org/10.1007/s12562-015-0863-x.

Yulianto, Irfan, Tasrif Kartawijaya, M.Z. Rafandi, Siska Agustina, Jessica Pingkan, Aminollah, Nurjamil, et al. 2016. "Profil Perikanan Tangkap." Dinas Kelautan dan Perikanan Provinsi Nusa Tenggara Barat dan Wildlife Conservation Society-Indonesia Program.

Yulianto, Irfan, Rian Prasetia, Efin Muttaqin, Tasrif Kartawijaya, Shinta Trilestari Pardede, Yudi Herdiana, Fakhrizal Setiawan, Rizya L Ardiwijaya, and Muhammad Syahrir. 2012. Panduan Teknis Pemantauan Ekosistem Terumbu Karang, Padang Lamun Dan Mangrove. Bogor, Indonesia: Wildlife Conservation Society dan Institute Of Natural and Regional Resources. 